\title{
The Effectiveness of Hospital Accreditation Implementation as a Protection Effort on Patient Information Rights
}

\author{
Anggraeni Endah Kusumaningrum ${ }^{1 *}$ \\ ${ }^{1}$ Faculty of Law, 17 Agustus 1945 University, Semarang, Indonesia
}

\begin{abstract}
This paper aims to analyze the effectiveness of the implementation of hospital accreditation in an attempt to provide legal protection of the right information of patients in hospital. The right to information stated on Article 7 and Article 8 of Law No. 36 of 2009 on Health as well as the shortcomings and advantages of health services. Along with the increasing awareness of the community to get good health service, raises the attitude of the critical patient. Patients no longer hesitate to ask the alternative treatment they will receive, whether in accordance with the cost incurred. The hospital is a complex organization because it is capital-intensive, energy, technology and various issues, covering the fields of law, economics, ethics, human rights, technology, and others with different principles and perspectives. The complexity of services in hospitals requires quality assurance and hospital service safety in the form of accreditation. Hospital accreditation is an acknowledgment given by an independent accrediting institution related to the assessment of the fulfillment of quality standards of hospital services on an ongoing basis. Therefore an accredited hospital is expected to effectively improve the quality of its services to their patients. The increased quality of hospital services will certainly improve patient safety and provide protection for patients.
\end{abstract}

\section{Introduction}

\begin{abstract}
Along with the increasing of public awareness to good health services, it also raises the attitude of critical patients. The patient's awareness arises because every medical action given has a risk that can cause pain, disability, or death [1]. Risks in health services can be caused by errors in the system [2]. Provision of health information systems by health service providers as obligations set out in the law and must be obeyed.[12] Patients want to get complete information about the health services they receive. It develops from the patient's rights because of the background of frequent violations of the patient's human rights [3]. The community does not hesitate to submit their complaints and even demanded medical staff through various means for health services that are deemed unsatisfactory [4].
\end{abstract}

* Corresponding author:anggraeni@untagsmg.ac.id 
In short, people want to get the best health services according to their conditions. Although, sometimes patients reject the medical action as they know the risk of the detailed medical action.

The hospital is essentially a complex organization, because it is capital intensive, human resources, technology, science, regulation, and solid problems such as: law, economics, ethics, human rights, technology, and others.(article 1UU No44 of 2009).The complexity of the service in hospitals requires quality assurance and service security that is set in the form of accreditation. At present the government through the Ministry of Health has required the implementation of hospital accreditation in order to improve hospital services in Indonesia, in order to realize optimal community health status [5].

Data on the Hospital Accreditation Commission (KARS) in 2017 has 2,379 hospitals both private and government in Indonesia and only 1,032 accredited hospitals. The accreditation status is spread from prime, middle, main and plenary levels. Meanwhile, $41 \%$ of hospitals are fully accredited, while small hospitals still have many initial levels, and this plenary status is mostly in private hospitals [11].

Accreditation in hospitals is based on Law No. 36 of 2009 which concerning on Health, Law No. 44 of 2009 about Hospitals and Permenkes 1144 / Menkes / Per / VIII / 2010 about the organization as well as the work procedures of the Ministry of Health. This hospital accreditation arrangement is expected to improve the quality of hospital services. Article 2 Permenkes No.34 of 2017 about Hospital Accreditation in lieu of Permenkes No. 12 of 2012 regulates that hospital accreditation aims to improve the quality of hospital services and protect patient safety, improve community protection, human resources in hospitals and hospitals as institutions, supporting the government program and increasing the professionalism of Indonesian hospitals in the eyes of the international community. Based on that, it is necessary to question how effective is the implementation of hospital accreditation as an effort to provide protection for patient information rights?

\section{Discussion}

\subsection{Right to Information as Patient Protection}

In order to provide legal protection for patients, what needs to be considered is that the parties (patients, doctors and hospitals) must understand the rights and obligations inherent in them. The relationship of patients, doctors and hospitals will lead to complementary rights and obligations referred to as therapeutic transactions[4]. Patients have the right to get the correct information related to health services that suit their needs, but patients are also obliged to provide correct information about the condition of the body and the pain that the patient suffers. Basically the right to obtain information in health services aims to clearly identify the disease and the actions to be taken in order to cure the disease. The process of determining the actions that the doctor will take at the hospital for the patient is certainly after the patient has received enough information, so that this information is the basis for an agreement to take a decision on the actions of the doctor to the patient.

Providing information about the patient's right is done since the patient enters and registered as a hospital patient until the patient has finished treatment and goes home. Therefore, it is very necessary to deliver information about the patient's rights as a patient or family comprehensively.

Article 32 of Law No. 44 of 2009 about Hospitals, regulates the rights of patients covering 18 things, namely: a). obtain information about the rules and regulations in the Hospital; b). obtain information about rights and obligations c) obtain services that are humane, fair, honest and without discrimination d) obtain quality health services in 
accordance with professional standards and standard operating procedures e) obtain effective and efficient services so that patients avoid physical and material losses; f) submit complaints about the quality of services obtained; g). choose a doctor and class of treatment according to his wishes and regulations that apply in the Hospital h) request consultation about the disease he suffered from other doctors who have a Practice Permit (SIP) both inside and outside the Hospital; i) get privacy and the confidentiality of the illness including medical data; j) obtain information that includes diagnosis and procedures for medical action, the purpose of medical action, alternative actions, risks and complications that may occur, and the prognosis of actions taken and estimated treatment costs; $\mathrm{k}$ ) approve or reject the actions that will be carried out by health personnel against the illness, 1) accompanied by his family in a critical condition, m) carry out worship according to the religion or belief he adheres to; n) obtain their own security and safety; o) submit proposals, suggestions, improve hospital treatment; $p$ ) refuse spiritual guidance services that are not in accordance with their religion and beliefs; q) sue and / or sue the Hospital if the Hospital allegedly providing services that are not in accordance with standards either civil or criminal; and; r) complaining about Hospital services that are not in accordance with service standards through print and electronic media in accordance with the provisions of the legislation.

Article 52 of Law No. 29 of 2004 about Medical Practice regulating information to patients at least includes: diagnosis and procedures for medical treatment; the purpose of medical action taken; other alternative actions and risks; risks and complications that may occur; prognosis for the actions taken (article 45 paragraph 3).

Article 2 paragraph 1 letter a PERMENKES No.4 / MENKES / PER / 2018 about Obligations of Hospitals and Obligations of Patients regulates that the Hospital is obliged to provide correct information about Hospital services to the public in the form of general information about hospitals and information related to services medical to patients. There are several things that must be considered regarding information to patients: Information must be given or not requested; Information does not use medical terms to be easily understood; Information must be provided in accordance with the level of education, condition, and situation of the patient; Information must be complete and honest, unless the doctor considers that the information can harm the interests or health of the patient or the patient refuses to be given information (KODEKI, article 5). Chapter III article 10 of the Hospital Code of Conduct (KODERSI) regulates one of the obligations of the hospital to the patient is to provide an explanation of what the patient has suffered, and what action must be taken.

Regarding the right to information in health services, Weisstub believes that the human right to health care is linked to the right of non-political freedom, health care is either life preserving or alleviating climate sickness or suffering which is the ability to develop fully as human being.[13]. Whereas according to Paul Shoukens said the access to information is sufficiently guaranteed. Accessibility included the right to seek, receive and import information and ideas regarding health issues. However, the right to have personal health data on access to information should not be treated with confidentiality. [14]

Based on the above opinion, it is concluded that the right to information in health services is the right of access as a basic social right that originates in human rights

\subsection{Hospital Accreditation}

In order to provide quality health services to the community, especially patients, the health care system in the hospital needs to be built. One of the strategic steps which taken by the government to build a health service system in order to improve the quality of health services through hospital accreditation. Since January 2018 an accreditation policy has been implemented in 2017, namely the National Standard of Hospital Accreditation Issue 1 
(SNARS Issue 1 of 2017). National Standards for Hospital Accreditation Issue 1 is a new standard of accreditation that is national and nationally applied in Indonesia.

Accreditation according to the national encyclopedia is a form of recognition given by the government to institutions or institutions. Philosophically, accreditation activities are a form of government attention and protection to the public (Article 40 paragraph 4 of Law No. 44 of 2009). Quality of service is in accordance with standards as professionalism and efficiency in service and positive hospital capability [6]. Article 1 point 1 of the Minister of Health Regulation No. 34 of 2017 about Hospital Accreditation is the government's recognition of the quality of hospital services to hospitals after an assessment has been made that the hospital has met the prescribed standards. Both standard facilities and service procedures as a guide to the level of achievement that must be met by the hospital (article 1 point 2 Permenkes No. 34 of 2017 about Hospital Accreditation).

The organization's accreditation arrangement aims to improve the quality of hospital services and patient safety, improve the protection of human resources in hospitals and hospitals as institutions, support government programs and increase the professionalism of Indonesian hospitals in the international eye. (Article 2 of Permenkes No. 34 of 2017). The accreditation is carried out by an independent institution that organizes accreditation from within or outside the country that conducts assessments on hospitals based on applicable accreditation standards. (Articles 3 and 4 of Permenkes No. 34 of 2017). Hospital accreditation is held regularly at least every 3 years.

The implementation of hospital accreditation includes three ways, namely basic, advanced and complete levels according to service activities. Basic level accreditation assesses five activities, including administration and management, medical, nursing, emergency and medical records. Advanced accreditation assesses 12 activities, namely 5 basic level activities plus pharmacy, radiology, operating rooms, infection control, high risk services, laboratories and work safety, fire and disaster awareness. Complete level accreditation assesses 16 activities, namely 12 advanced services plus intensive services, blood transfusion, medical rehabilitation and nutrition. Accreditation with this system is considered not comprehensive because hospitals can choose accreditation for 5 (five), 12 (twelve) or 16 (sixteen) services, so that the hospital quality standards can differ depending on how many accreditation services are followed. This was the development of 5 service accreditation in 1995, 12 services in 1998 and 16 services in 2002 which were evaluated by the accreditation in the 2012 version. Evaluation is a policy oversight mechanism [7]. The accreditation policy for the 2012 version is a policy development that departs from the need for comprehensive service standards. This accreditation standard refers to the International Principles for Healthcare Standards, A Framework for requirements for standards, 3rd Edition in 2007, Joint Commission International Accreditation Standards for Hospitals 4th Edition in 2011, a hospital accreditation instrument in 2007 which was supplemented by local content in the form of national priority programs namely the Millennium Development Goals (MDG's) program includes PONEK, HIV and TB DOTS as well as standards that apply at the Ministry of Health of the Republic of Indonesia.

One measure in the procedural dimension of hospital accreditation is the rights and obligations of patients, doctors and hospitals as a technical operational policy charge in hospital bylaws (HBL). Hospital by laws consists of two words, hospital which means hospital and bylaws. Guwadi interpreted bylaw as a set of laws or rules formally adopted by a faculty organization [8]. So bylaws are defined as rules and provisions made by an organization or association to regulate its members.

The existence of HBL is important in its role as a disciplinary and guarantees legal certainty in the hospital because it is a rule of play from and in hospital management. One of the characteristics of HBL is tailoring made, meaning that the substance content and detailed formulation of HBL are not necessarily the same in every hospital. HBL is also an 
extension of the law, from the general to the special. If the hospital has made HBL well, of course the hospital has carried out accreditation [9]. Hospital accreditation in the procedural dimension of service quality uses the Donabedian concept which explains the link between hospital accreditation and the quality of health services [10].

The guidance and supervision of accreditation is carried out by the minister or governor according to the duties of his authority. If there are irregularities, the minister through the relevant director general gives verbal or written reprimands (Article 14 of Permenkes No. 34 of 2017). The Director General's actions "can" include an independent appraiser accreditation agency to reevaluate the compliance with accreditation standards with the accreditation status. If the results are not appropriate, the institution "can" revoke the determination of the accreditation status (Article 15 of Permenkes No. 34 of 2017).

Hospital accreditation plays a role in the legal protection of the right to information of a patient. However, if we look at the practice even though the hospital has been accredited, violations of the right to patient information are still common, especially in Permenkes No. 34 of 2017 that has not regulated the legal consequences of the violation. The provisions of articles 14 and 15 of the Regulation of the Minister of Health No. 34 of 2017 which regulate irregularities in the implementation of accreditation can be given administrative sanctions and have not been able to provide protection; precisely the regulation of the two articles has the potential to cause legal uncertainty.

\section{Conclusion}

Hospital accreditation serves to provide legal protection for the right to patient information, as a procedural measure for fulfilling the rights and obligations of patients, doctors and hospitals. However, even though the hospital has been accredited, this violation of the right to information of patients still occurs, moreover Permenkes No. 34 of 2017 does not regulate the legal consequences of the violation.

\section{References}

1. H. Sungkowo, W. R. Adawiyah, B. Aji, Efektifitas Pemberian Informasi Hak Pasien Dalam Pelayanan Di Rumah Sakit Islam Fatimah Cilacap, JEBA 20, 2, (2018).

2. H. Idris, Dimension Of Patient Safety Culture, JIKM 8, 1, Pp 1 - 9 (2017).

3. J. Cohen and Ezer, Human Right Inpatient Care: A Theoritical And Practical Frame Work. US National Library of Medicine, Health And Human Right Journal, 15, 2, (2013), http//www.ncbi.nih.gov/pubmed/24421170 (2013).

4. E. Siregar, and A. Budhiarti, Perlindungan Hukum Hak-Hak Pasien Dalam Transaksi Terapeutik, Majalah Hukum Forum Akademika vol 24, Pp 172 - 194 (2013),

5. S. Wahyudi, Tanggung Jawab RS Terhadap Kerugian Akibat Kelalaian Tenaga Medis Dan Implikasinya, JDH 11, 3, Pp 505 - 521 (2011).

6. Poerwani and E. Sopacua, Akreditasi Sebagai Upaya Peningkatan Mutu Pelayanan Rumah Sakit, Buletin Penelitian Sistem Kesehatan 9, 3, Pp 125 - 133 (2006).

7. Ayuningtyas, Kebijakan Kesehatan Prinsip dan Praktik. (Rajawali Pers, Jakarta, 2014).

8. J. Guwandi, Dokter dan Rumah Sakit, (Fak. Kedokteran Universitas Indonesia, Jakarta, 1991).

9. N. Lumenta, Akreditasi Rumah Sakit Di Luar Negeri, (Makalah Dalam Pelatihan Akreditasi RS Di Dinkes Provinsi DKI, Jakarta, 2003) 
10. Lumenta, Citra, Peran dan Perilaku, (Kanisius, Yogyakarta, 2008).

11. Komisi Akreditasi Rumah Sakit ( KARS), (2017).

12. E. Wahyati, Hak Atas Informasi Publik Dan Hak Atas Rahasia Medis: Problem HAM Dalam Pelayanan Kesehatan, PJIH 1, 2, Pp 248 - 269 (2014).

13. Weisstub, N. Davit, P. G. Diaz, Autonomy And Human Right In Health Care, (Springer, Dondrecht-Netherlands, 2008)

14. A.P. den Exter ( eds), International Health Law Solidarity inJustice and Health Care, (Maklu, Antwerpen, 2008) 